\title{
Implementation of Life Kinetic Mental Training Method in Order to Improve the Competency of Coaches in Psychological Training for Athletes
}

\author{
Novrizal Achmad Novan*, Nidaul Hidayah, Bambang Erawan, Komarudin Komarudin, Patriana Nurmansyah \\ Awwaludin, Ridha Mustaqim \\ Sport Coaching Education Dept, Faculty of Sport and Health Science Education \\ Universitas Pendidikan Indonesia \\ Bandung, Indonesia \\ *novrizal@upi.edu
}

\begin{abstract}
This research based-community service is carried out based on the fact that sports achievement development in Ciamis regency is still relatively low and only certain sports could achieve medals at the 2014 West Java Regional Sports Games (PORDA), in Bekasi. This study was conducted as an education and training program in the form of Life Kinetik implementation training methods for sports coaches. So that they will understand this training method and able to implement it during their coaching session. Sports achievement on that regency has dramatically decreased in recent years. Whereas, on previous PORDA, Ciamis regency was one of the barometer cities in West Java for sports achievement. This is because that regency had many representatives to compete on National Sports Games (PON). The observational trial method used in this study. 28 sports coaches that members of the National Sports Committee in the Ciamis Regency were involved. Based on the findings, we can conclude that Life Kinetik training program gives significant psychological effects for athletes to be applied in training sessions.
\end{abstract}

Keywords: coach competencies, life kinetic; mental training, training method

\section{INTRODUCTION}

Social perceptions in sports for the psychological aspects of athletes are very important to keep athletes in order to sustain in a competitive climate [1]. For this reason, every athlete must possess good psychological skills. This should be a concern of the coach in planning a training program by including a mental training program for the athletes. Physical training and techniques that are often boring and tiring must be balanced with pleasant mental exercises. Life Kinetik is a new and unique form of mental training while the working principle of the brain from simple concepts to complex and unique concepts was demanded. Life Kinetik is a type of mental training that is rarely known in Indonesia. In addition, athletes are not only required to excel in their abilities of physical, technical and tactical aspects in sports, but athletes are also required to be smart and focus on their obligations as athletes in presenting their duties [2].
The psychological training program is very important for athletes so that athletes focus on the tasks that must be done, athletes will be more focused on deploying their maximum potential or abilities despite stresses and challenges facing them during competition. The results of good athlete development will be reflected in the achievements of medals in each competition. Besides, the competence of qualified coaches can mediate the positive effects of coach leadership on athlete satisfaction [3]. Psychological skills for coaches can refer to assumptions, risk-taking, and the ability to influence athletes. Such coaches can encourage creativity so that their athletes will be able to follow their instructions well without worries. The more competent a coach is, the more authoritative and beloved they will be.

People are said to be competent when they show their abilities. In addition, we must be able to answer what competency challenges are needed in developing sports achievements. But the conditions clearly showed that the development of sports performance in the Ciamis Regency is relatively low. Only certain sports that could get a medal at PORDA Bekasi in 2014. Sports achievements of the Ciamis Regency have decreased quite dramatically in recent years. A very actual fact was found that the sports achievements in the 2006 PORDA, Ciamis was ranked 11th with 20 golds, 30 silvers, and 37 bronzes. In 2010 PORDA was still ranked 11th with the acquisition of 15 golds, 16 silvers, and 30 bronzes. But the most concerning condition is the achievement in 2014 PORDA, Ciamis Regency's achievements continued to decline until it was ranked 26th with 6 golds, 10 silvers, and 11 bronzes, from 28 sports that were competed.

A competition attended by athletes turns out to have another purpose that is often implied, not only achievement but as a show of pride for each region that delegates athletes. Training and development carried out by each region contingent is very competitive and is made a priority in each region with the aim to be the best among other regions. On the other hand, the glorious achievements of each region will have a positive impact on their regional economy as well as the welfare of their athletes [4]. 
One of the reasons for the low sports performance due to the low quality of coaching. In addition, there are also other issues such as lack of government attention, inadequate facilities, application of technology that is not optimal, coaches are less professional, and psychological aspects of coaching are still ignored [5]. In fact, experts agreed that physical, technical, tactical, and psychological variables are predictors of the athlete's success in sports and must be carried out simultaneously in the training process [6].

Efforts that have been made by the government along with the National Sports Committee to improve sports achievements in Ciamis Regency are a good strategy. However, other strategies related to the implementation of the training and training process must be a priority strategy in order to achieve maximum performance. The effort of the sports coaches, in this case, is how to keep all the athletes keep focused on the tasks that must be done so that the performance displayed remains consistent from time to time, including in competitive situations.

The fact that training programs to still only concentrate on developing physical abilities, techniques, and tactics, meanwhile the development of psychological aspects are ignored. Competencies improvement of coaches in improving the psychological aspects of athletes especially improving physical condition, cognitive function, and other psychological aspects will be useful in improving athlete performance. Therefore, one of the efforts that can be done to improve the trainer competencies is through mental training including Life Kinetik training for coaches.

In Indonesia, Life Kinetik is not widely known among athletes and coaches. Life Kinetik combines forms of exercise in the form of motion activities, cognitive challenges, and visual perception exercises, especially peripheral visual perception. The exercise of Life Kinetik method consists of various basic movements such as throwing, catching, and handeye coordination. With the combination of motion and cognitive demands of Life Kinetik, it is expected to be able to contribute to psychological stimulation in the training given to athletes by coaches.

Low competence levels among coaches in preparing training programs will have a negative impact on athlete performance. Therefore, the physical, technical, tactical, and mental training programs must be well prepared by the coaches on their goals so that athletes are ready to compete in accordance with the targets set [7]. But what the government has forgotten is the improvement of human resources quality in sports. If the government and the national sports committee start to change the pattern of sports coaching as a whole by optimizing all aspects including psychological coaching for all coaches and athletes, sporting achievements will probably gradually increase towards the expected maximum performance [8].

The purpose of this study is to improve the competence of trainers in improving the psychological aspects of athletes, especially improving physical condition, cognitive function, and other psychological aspects that will be useful in improving athlete performance.

\section{METHODS}

This study used an observational trial method among sports coaches that members of the National Sports Committee in Ciamis Regency. The method used to question the knowledge received and explain the social changes that can occur to them. The subjects in this study were 28 coaches selected through purposive sampling with an average age of 38.4 years with a different educational background.

They were divided into two groups: participant and nonparticipant groups. In observing the participant group, the researcher intervenes in the environment. This refers to including the trainer as a group member, which aims to observe inaccessible behaviour. Data obtained from 13 meetings by monitoring and evaluation of the implementation Life Kinetik method training program mastery on the training process in various sports.

The implementation of Life Kinetik training program was conducted twice a week. The program was given during the study consists of ladders exercise, jumping the line, immediate reaction, and cognition, cross jumping, juggling, and rainbow running.

\section{RESULTS}

\section{A. Life Kinetik Influences Athlete's Concentration}

Data obtained shows that $92.9 \%$ of observational group members feel that Life Kinetik could improve the athlete's concentration. Physical activity exercises, in this case, Life Kinetik training is very good for the brain, because: First, exercise can improve circulation so that the nerves of individuals can get more oxygen and nutrients. Second, exercise can stimulate dopamine production which is one of the neurotransmitters that improves mood [9]. If the Life Kinetik training conducted with an adequate amount of 40-60\% with a low intensity based on pleasure then the exercise can increase the production of new cells in the brain [10]. The growth of new cells in the brain (neurogenesis) correlates with memory [11].

\section{B. Life Kinetik Fosters Athlete's Motivation}

Data obtained shows that $92.9 \%$ of observational group members feel that Life Kinetik motivates the athlete to get involved in training. Life Kinetik training contains a combination of motion activity, cognitive challenges, and visual perception exercises, specifically peripheral visual perception. The training is fun and athletes are not required to fully master the motion patterns, but only 40-60 percent. So that Life Kinetik training really avoids monotonous, boring, and frustrating forms of exercise, because in complex technical and motion exercises it involves more coordination of nerves and muscles, athletes cannot make movements in a tired state but athletes must continue to enjoy the movement.

\section{Life Kinetik Influences Athlete's Confidence}

Data obtained shows that $96.4 \%$ of observational group members feel that Life Kinetik influences the athlete's confidence. Athletes who have confidence will certainly have a strong perception of the athlete that he has the ability, has an 
excellent physical condition, and clear goals, this will challenge athletes to do their job properly [12]. In the Life Kinetik training, the motion tasks that athletes must do are very complex, so that they demand good motion coordination skills, the motion tasks in kinetic life are very challenging for athletes to try to repeat every movement until the athlete is able to perform each movement task successfully [13].

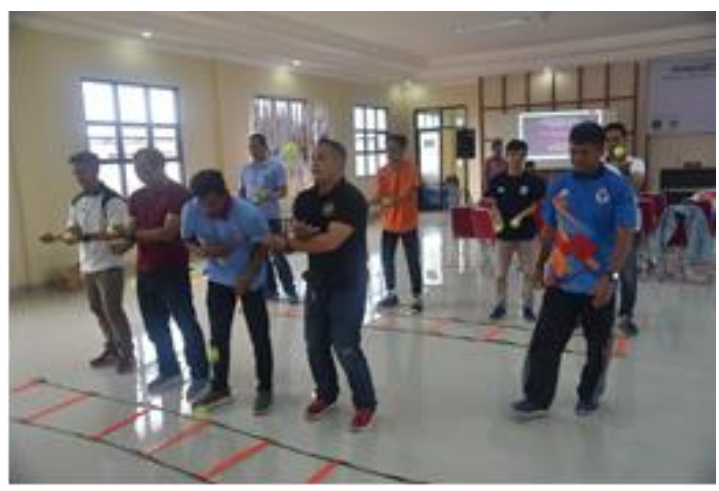

Fig. 1. Life kinetik training program implementation by coaches.

In fact, to do every movement of the Life Kinetik training athletes rarely to succeed at once, but they will make it through repeated repetitions that require good concentration and coordination.

\section{Life Kinetik Fosters Athlete's Skill Acquisition}

Development of the basic abilities of the brain is done by developing sensory-motor abilities through physical activities, one of which is included in the Life Kinetik training. Data obtained that $85,7 \%$ of observational group members feel that Life Kinetik can foster particular sports skill acquisition. The process of association and sensory integration, as well as sensory-motor interaction, are key to success in the learning process and it can be implemented through physical activities. Once the importance of the brain basic abilities appears in the involvement of many structures that are vital and essential for the development of the skill learning process. Based on the science of neuroscience that brain function and growth are the results of physical exercise. The brain to be able to function properly really needs the basic elements of oxygen, blood, and water, this is very important for learning [14].

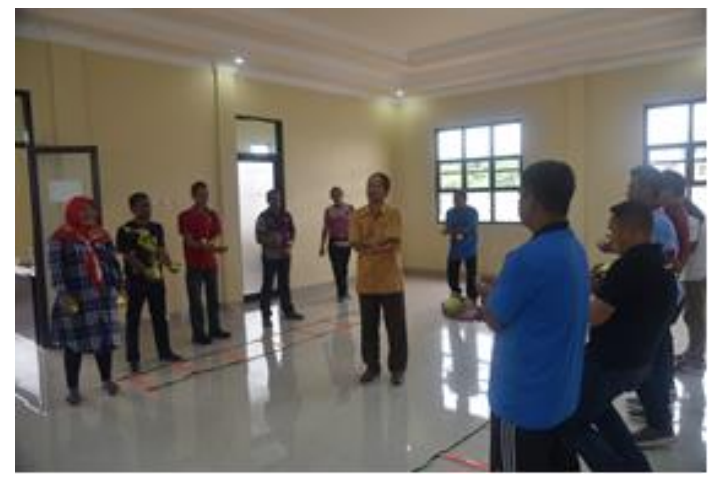

Fig. 2. The exercise of life kinetik method consists of various basic movements.

\section{DISCUSSION}

Life Kinetik emphasizes the combination and coordination of activities, the challenges of cognition that continue to increase in difficulty, and visual perception created through patterns of motion and controlling objects. Some research says that the Life Kinetik exercise involved in the formation of new synapses inside the brain.

Long-term interventions are believed to produce different effects from the two interventions even for cognitive abilities and cause a stronger effect altogether [15]. Psychological and psychosocial interventions can have a positive effect on sports performance, but these interventions must be carried out continuously so that the effects can survive on athletes [16].

Based on this condition, the Ciamis Regency government along with the National Sports Committee in Ciamis Regency must conduct some reflections and look for solutions so that the glorious achievements of previous years can be proven and achieved again. The reason for the low sports performance due to the low-quality human resources that lack information in order to boost athletes' performance [17].

Despite interpersonal relationships are essential for success, Cooperation between sports institutions starts from the national sports committee in Ciamis regency with institutions that develop sports science needs to be held regularly. In addition, there are also other issues such as lack of government attention, inadequate facilities, minimum technological application, uncertified coaches, and psychological aspects of coaching are still ignored.

While experts prove that physical, technical, efforts, and psychological variables are successful predictors in sports and must be carried out simultaneously in the training process [18]. These four aspects of training are factors that determine the quality of training and contribute to the performance of athletes, both individually and in teams [19]. The good relationship between athletes and coaches will build and maintain them on a good path in the transfer of knowledge and the development of sporting achievements, forming a system capable of defining the effectiveness and success of sports development [20].

Athletes while showing performance are highly demanded to have various maturities in all aspects one of which is maturity in psychological aspects. Maturity is an effective effort to achieve maximum performance in every sport. Thus the effort of the sports coach, in this case, is how to keep all the fostered athletes focused on the task that must be done so that the performance displayed remains consistent from time to time including in the competition situation.

\section{CONCLUSION}

Based on the findings, we can conclude that life kinetik training program gives significant psychological effects to be applied in training sessions. Therefore, the author hoped this training for coaches and sports athletes could be is in their program. Life Kinetik as a training method to improve athlete performance, which is in accordance with cognitive function, which is composition and intelligence. 
[6] N.A.V. Coker, "Predictors of competitive success of national-level powerlifters: a multilevel analysis," International Journal of Performance Analysis in Sport, vol. 18(5), pp. 796-805, 2018.

Furthermore, positive commitments from athletes and coaches will be related to performance and achievement of goals. The view competency-based coach training implies that skills and relationships in developing sports are closely related. Athlete's confidence in good coach competency will be positively correlated significantly with their psychological dimensions, strategy, physical condition, techniques in achieving sports performance goals. Thus, coach competence, the relationship between athletes and coaches, and commitment will have an impact on achieving higher goals.

\section{ACKNOWLEDGMENT}

Firstly, I would like to express my special thanks of gratitude to the Faculty of Sport and Health Education as well as the Sport Coaching Department who have funded this study. Secondly, My deepest gratitude goes to National Sports Committee in Ciamis Regency who gave me the golden opportunity to do this wonderful project, which also helped me in doing a lot of research and I came to know about so many new things I am really thankful to them.

\section{REFERENCES}

[1] J.D. DeFreese and A.L. Smith, "Athlete social support, negative social interactions, and psychological health across a competitive sport season," Journal of sport and exercise psychology, vol. 36(6), pp. 619630, 2014.

[2] K. Komarudin and P.N. Awwaludin, "Life Kinetik Training in Improving the Physical Condition of Football Athletes," In 3rd International Conference on Sport Science, Health, and Physical Education (ICSSHPE 2018). Atlantis Press, 2019.

[3] Kao, San-Fu, and Chou-Yu Tsai, "Transformational leadership and athlete satisfaction: the mediating role of coaching competency," Journal of Applied Sport Psychology vol. 28, no. 4, pp. 469-482, 2016.

[4] J. Singh, C. Singh, and M. Singh, "Mental Skills: A Comparison between Volleyball and Football Players," International Multidisciplinary e -Journal, vol. 122, 2015.

[5] T. Absalyamov, "The influence of cultural and sport mega-events on sustainable development of the city," Procedia-Social and Behavioral Sciences, vol. 188, pp. 197-201, 2015.
[7] D. Gould, "Conducting Impactful Coaching Science Research: The Forgotten Role of Knowledge Integration and Dissemination," International Sport Coaching Journal, vol. 3(2), pp. 197-203, 2019.

[8] L. Norman, "It's sport, why does it matter? ' Professional coaches' perceptions of equity training," Sports Coaching Review, vol. 7(2), pp. 190-211, 2018.

[9] E. Jensen, "Brain-based education in action," Educational Horizons, vol. 90(2), pp. 5-6, 2011.

[10] Demirakca, "The Exercising Brain : Changes in Functional Connectivity Induced by an Integrated Multimodal Cognitive and Whole-Body Coordination Training," Neural Plasticity, pp. 1-11, 2016.

[11] Y.S. Kitabatake, "Adult neurogenesis and hippocampal memory function: new cells, more plasticity, new memories?," Neurosurgery Clinics, vol. 18(1), pp. 105-113, 2007.

[12] E. Heper, S. Yolacan, and S. Kocaeksi, "The Examine Goal Orientation and Sports Self Confidence Level of Soccer Players," Procedia - Social and Behavioral Sciences, vol. 159, pp. 197-200, 2014.

[13] L. Crust, "Challenging the 'Myth' of a Spiritual Dimension in Sport," The Online Journal of Sport Psychology, vol. 8(2), pp. 17-26, 2006.

[14] E. Jensen, "Brain-based education in action," Educational Horizons, vol. 90(2), pp. 5-6, 2011.

[15] M. Thomas, "The Effect of Different Movement Exercises on Cognitive and Motor Abilities," Advances in Physical Education, vol. 2(4), pp. 172-178, 2012.

[16] D.J. Brown and D. Fletcher, "Effects of Psychological and Psychosocial Interventions on Sport Performance: A Meta-Analysis," Sports Med, vol. 47, pp. 77-99, 2017.

[17] H. Wang, Y. Sui, F. Luthans, D. Wang, and Y. Wu, "Impact of authentic leadership on performance: Role of followers' positive psychological capital and relational processes," Journal of Organizational Behavior, vol. 35(1), pp. 5-21, 2014.

[18] T. Heinen, "Do Static-Sport Athletes and Dynamic-Sport Athletes Differ in Their Visual Focused Attention?," The Sport Journal, 2011.

[19] R.B. Lidor, "Psychological aspects of training in European basketball: Conceptualization, periodization, and planning," The Sport Psychologist, vol. 21, pp. 353-367, 2007.

[20] S. Jowett, "Coaching effectiveness: The coach-athlete relationship at its heart," Current Opinion in Psychology, vol. 16, pp. 154-158, 2017. 